\title{
AIR POLLUTION AND SEMEN PARAMETERS IN MEN SEEKING FERTILITY TREATMENT FOR THE FIRST TIME
}

\section{ARTUR WDOWIAK ${ }^{1}$, EDYTA WDOWIAK ${ }^{2}$, AGNIESZKA BIEŃ ${ }^{3}$, IWONA BOJAR ${ }^{4}$, GRAŻYNA IWANOWICZ-PALUS ${ }^{3}$, and DOROTA RACZKIEWICZ}

${ }^{1}$ Medical University of Lublin, Lublin, Poland

Faculty of Health Sciences, Diagnostic Techniques Unit

${ }^{2}$ International Scientific Association for the Support and Development of Medical Technologies, Lublin, Poland

${ }^{3}$ Medical University of Lublin, Lublin, Poland

Faculty of Health Sciences

${ }^{4}$ Institute of Rural Health in Lublin, Lublin, Poland

Department for Woman Health

${ }^{5}$ SGH Warsaw School of Economics, Warsaw, Poland

Institute of Statistics and Demography, Collegium of Economic Analysis

\begin{abstract}
Objectives: The purpose of this paper was to analyze the relationship between the selected chemical air pollutants found in the Lublin Province and the semen parameters of men seeking fertility treatment for the first time. Material and Methods: The study involved an analysis of semen sample test results obtained from male patients first reporting for fertility treatment in reproductive health centers in the Lublin Province, Poland. The data set comprises semen parameters of 13148 men, and the number of samples in the reference period was 255-769 annually. Data on air pollution were obtained from the website of the Polish General Environmental Inspectorate and included selected chemical air pollutant levels, i.e., $\mathrm{NO}_{2}, \mathrm{SO}_{2}, \mathrm{O}_{3}$, and $\mathrm{PM}_{10}$. Results: The mean $\mathrm{PM}_{10}$ levels in the air increased, on average, by $0.65 \mu \mathrm{g} / \mathrm{m}^{3}$ annually in 2000-2015 ( $\left.\mathrm{p}=0.029\right)$; the mean levels of $\mathrm{O}_{3}$, $\mathrm{NO}_{2}, \mathrm{SO}_{2}$ did not change significantly in the analyzed period. There were increasing trends in the mean sperm density and total sperm count of the subjects in 1992-2015 ( $<$ 0.001). The mean percentage of sperm with normal morphology significantly decreased in the subsequent analysis periods: 1992-1998 ( $p=0.001) ; 1999-2009$ ( $p<0.001) ; 2010-2015$ ( $p=0.001)$. A significant negative correlation was found between the ozone levels in the air in the Lublin Province and the percentage of sperm with normal morphology $(\mathrm{r}=-0.8311, \mathrm{p}=0.040)$. Conclusions: Exposure to ozone in the air contributes to decreased percentages of sperm with normal sperm morphology. Over the years, there was an increasing trend in sperm density in the men first reporting for fertility treatment, and a decreasing trend in the percentage of sperm with normal morphology. Int J Occup Med Environ Health. 2019;32(3):387-99
\end{abstract}

Key words:

air pollution, reproductive health, male infertility, semen analysis, sperm, sperm quality

Received: April 22, 2018. Accepted: January 29, 2019.

Corresponding author: Agnieszka Bień, Medical University of Lublin, Faculty of Health Sciences, Staszica 4/6, 20-081 Lublin, Poland (e-mail: agnesmbien@gmail.com). 


\section{INTRODUCTION}

Air pollution is the main cause of global threats to the environment and to the human population. Its sources include emissions of various chemical compounds from industrial plants, vehicles, and households [1]. The poor air quality found in Poland is mainly caused by emissions from households and road transport, with large amounts of exhaust and flue gases released into the atmosphere [2].

In Europe, pollutant emissions are constantly monitored by the European Environment Agency (EEA). AirBase is the air quality information system operated by the EEA through the European topic centre on air pollution and climate change mitigation. It contains air quality data delivered annually under Council Decision 97/101/EC (Exchange on Information Decision) [3]. The Agency data indicate that air pollution is the most severe in Poland and Bulgaria [4]. In Poland, air pollution is monitored within the National Environment Monitoring framework, developed by the Chief Environmental Inspector and approved by the Minister of Environment. Air quality in Poland is monitored with regard to the following 12 pollutants: sulfur dioxide, nitrogen dioxide, carbon oxide, benzene, ozone, suspended particulate matter (particulate matter with a particle diameter $<10 \mu \mathrm{m}\left[\mathrm{PM}_{10}\right]$ and with a particle diameter $\leq 2.5 \mu \mathrm{m}$ $\left.\left[\mathrm{PM}_{2.5}\right]\right)$, and pollutants contained in $\mathrm{PM}_{10}$ : lead, arsenic, cadmium, nickel, and benzo(a)pyrene $(\mathrm{BaP})$ [5].

In Poland, air pollution contributes to approx. 45000 premature deaths annually, and $97 \%$ of Poles breathe air classified as harmful in accordance with World Health Organization (WHO) guidelines [4,6]. Inhaled particulate matter is immediately carried through the bloodstream to the kidneys, liver, brain, and other tissues, disrupting their physiology [1]. In 2005, the WHO announced that $\mathrm{PM}_{2.5}$ and $\mathrm{PM}_{10}$ may be detrimental to human health (by contributing to cancer, respiratory diseases, and cardiovascular diseases), even at half the concentrations considered allowable in the European Union [6]. Problems related to air pollution and adverse health effects are on the rise [4].
According to Lelieveld et al., model projections based on a business-as-usual emission scenario indicate that the contribution of outdoor air pollution to premature mortality could double by 2050 [7].

The literature includes numerous reports confirming the adverse impact of chemical factors on semen quality [8-15]. Exposure to air pollutants is associated with decreases in sperm motility, density, and the percentage of sperm with normal morphology. These substances also increase sperm DNA fragmentation, contribute to disomy of chromosomes 21 and $\mathrm{Y}$, and affect sex differentiation (the $\mathrm{Y}: \mathrm{X}$ sperm ratio) $[11,16]$. The harmful effects of air pollution can be explained by oxidative stress $[2,17,18]$. Human reproductive capability has decreased in recent years, as confirmed by a number of scientific reports [19-21]. Undoubtedly, this decreased fertility is also associated with the fact that in many European countries the decision to have children is increasingly postponed until an older age $[22,23]$. Environmental factors, including pollution in the lower layer of the atmosphere, are also significant to human fertility [24-26]. Though many studies have demonstrated an association between air pollution and fertility in animals, including in particular semen quality, this relationship remains unclear in humans [27,28]. The purpose of this paper was to analyze the relationship between the selected chemical air pollutants found in the Lublin Province and the semen parameters of men first reporting for fertility treatment.

\section{MATERIAL AND METHODS}

\section{Study group}

The study involved analyzing semen sample test results obtained from male patients who reported for fertility treatment in the years 1992-2015 to the major reproductive health centers in the Lublin Province, Poland, i.e., the Independent Public Teaching Hospital No. 1, the Luxmed Medical Centre, and the privately-owned "Ovum" Fertility Clinic. Analyses were performed on a set of seminograms in men who had abstained from sexual activity and 
alcohol consumption for 3-5 days before the test. Seminograms revealing azoospermia were excluded from the study. The data set comprised semen parameters of a total of 13148 men, and the number of samples in the analyzed period was 255-769 annually. The study was approved by the Bioethics Committee of the Rural Health Institute in Lublin (approval No. 24/2013).

\section{Air pollution data and exposure assessment}

Data on air pollution were obtained from the website of the Polish General Environmental Inspectorate and included selected chemical air pollutant levels in the years 2000-2015. The analyses included the levels of nitrogen dioxide $\left(\mathrm{NO}_{2}\right)$, sulfur dioxide $\left(\mathrm{SO}_{2}\right)$, ozone $\left(\mathrm{O}_{3}\right)$, and suspended particulate matter with a particle diameter below $10 \mu \mathrm{m}\left(\mathrm{PM}_{10}\right)$. The selection of air pollutants for the analyses was based on the availability of data for long time series in the Lublin Province.

\section{Semen analysis}

Semen tests were performed by laboratory diagnostics specialists whose skills are regularly verified by the Polish Society of Andrology. The testers used an internal quality assurance system, ensuring result reproducibility, and worked simultaneously in the 3 centers selected for the study. Such data as ejaculate volume, total sperm count, sperm density, and the percentages of sperm with progressive motility and with normal morphology have been available in medical documentation since 1992, but the percentage of viable sperm has only been tested since 2000.

Semen was tested in accordance with the 1992 WHO guidelines [29] from the beginning of the study period until 1998, with the 1999 WHO guidelines [30] - until 2009, and with the 2010 WHO guidelines [31] - from 2010 on. The 2010 WHO guidelines for motility analysis only include an evaluation of sperm progression or lack thereof.

The older, 1992 and 1999, versions of the WHO guidelines distinguished between rapid and slow progression; therefore, in the present study, data from the 2 categories were summarized to obtain results comparable with those obtained under the 2010 WHO guidelines. Due to the changes in sperm morphology evaluation methods introduced in the $2010 \mathrm{WHO}$ guidelines [31], the percentage of sperm with normal morphology was analyzed separately for 3 periods: 1992-1998 (in accordance with the 1992 WHO guidelines [29]), 1999-2009 (the 1999 WHO guidelines [30]), and 2010-2015 (the 2010 WHO guidelines [31]).

\section{Statistical analysis}

Statistical analyses were performed using the STATISTICA software (StatSoft, Poland). Linear trends were estimated for the time series of air pollutants in the years 2000-2015, and for the average age of men and mean semen parameters in the years 1992-2015. Regression models of the above-mentioned variable with the explanatory variable, representing the number of time series, along with the coefficient of determination and Pearson's correlation coefficient, were used. Pearson's coefficient was also used to analyze the correlation between age and semen parameters, and between air pollutants for the region in which the examined men lived and mean semen parameters in years 2000-2015. Due to the large sample sizes for each year (including several hundred men), parameter estimators were asymptotically normal distributed according to the central limit theorem and, consequently, statistical tests for large samples were used. The value of $\mathrm{p}<0.05$ was considered to be statistically significant.

\section{RESULTS}

\section{Air pollution in the study period}

In the years 2000-2015, the mean atmospheric $\mathrm{PM}_{10}$ levels in the Lublin Province increased, on average, by $0.65 \mu \mathrm{g} / \mathrm{m}^{3}$ annually $\left(\mathrm{y}=0.65 \mathrm{t}+23.26, \mathrm{R}^{2}=0.318\right.$, $r=0.564, p=0.029)$, whereas the mean ozone, nitrogen dioxide and sulfur dioxide levels did not change significantly in the analyzed period (Figure 1). 


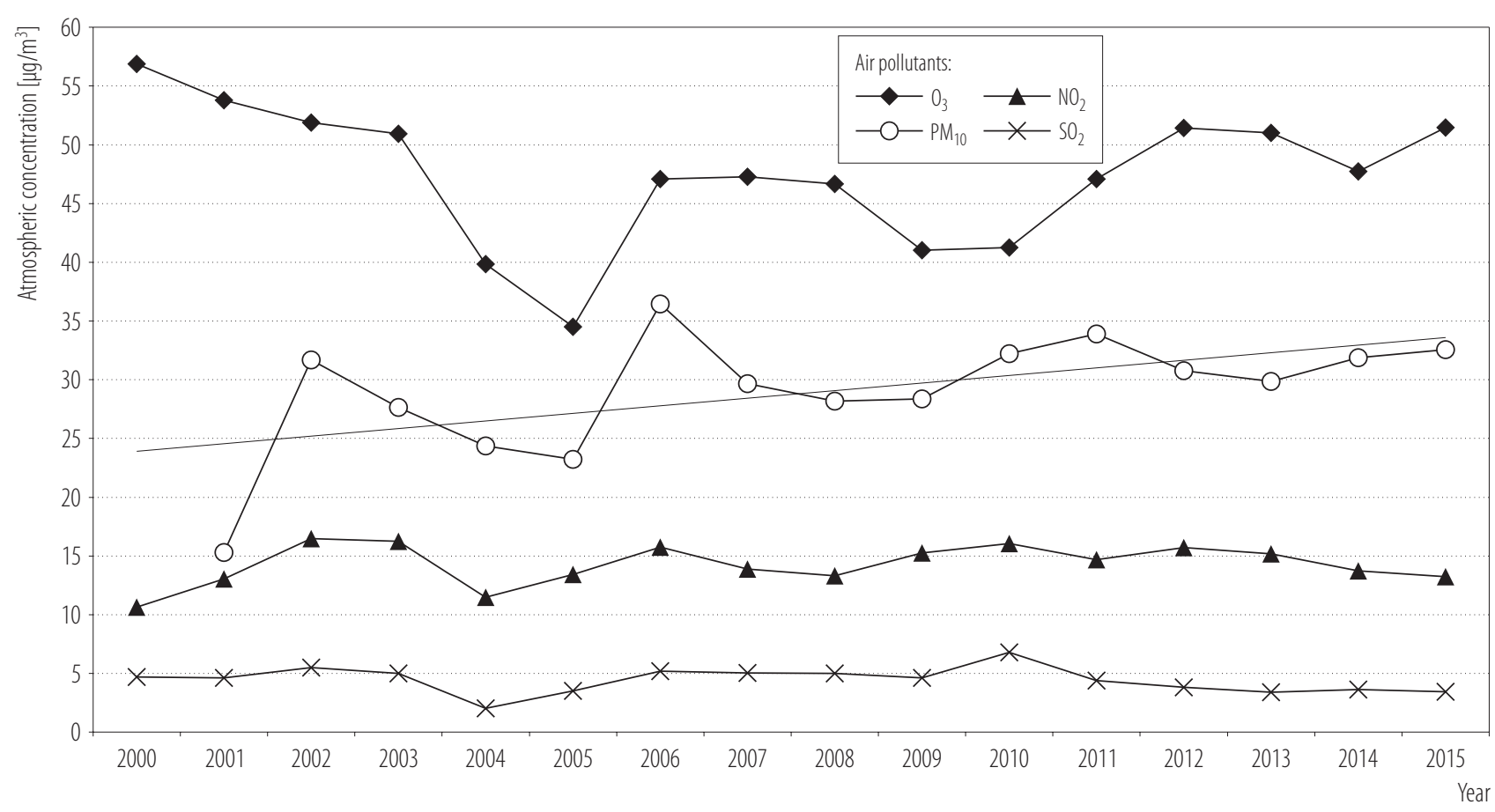

Figure 1. Air pollution in the Lublin Province, Poland, 2000-2015

\section{Study group characteristics}

An analysis of the age of men reporting for fertility treatment in the Lublin Province showed an increasing trend in the average age $\left(y=0.096 t+30.673, R^{2}=0.779, r=0.883\right.$, $\mathrm{p}<0.001$ ) (Figure 2).

\section{Changes in semen parameters}

An increasing trend in mean sperm density was fitted in the years 1992-2015 $\left(\mathrm{y}=1.0879 \mathrm{t}+17.562, \mathrm{R}^{2}=0.7437\right.$, $\mathrm{r}=0.862, \mathrm{p}<0.001)$. Mean sperm density was the lowest in 1992, at $18.3 \mathrm{~m} / \mathrm{ml}$. The maximum mean value of $48.6 \mathrm{~m} / \mathrm{ml}$ was found in 2010 and, subsequently, sperm density decreased again (Figure 3). Mean ejaculate volume ranged from $3.10 \mathrm{ml}$ in 1998 to max $4.76 \mathrm{ml}$ in 2009, without any significant upward or downward trends in the years 1992-2015 $(\mathrm{r}=0.289, \mathrm{p}=0.171)$ (Figure 4).

Total mean sperm count increased, on average, in the years 1992-2015 $\left(\mathrm{y}=5.3676 \mathrm{t}+56.001, \mathrm{R}^{2}=0.7609\right.$, $r=0.972, p<0.001)$. The lowest mean total sperm count was found in 1999 (72.1 million), and the highest in 2009 (190 million) (Figure 5).

The mean percentage of sperm with normal morphology decreased significantly every year:

- in 1992-1998: $y=-1.0365 t+61.735, \mathrm{R}^{2}=0.8915$, $\mathrm{r}=0.944, \mathrm{p}=0.001$,

- in 1999-2009: $\mathrm{y}=-3.1521 \mathrm{t}+59.233, \mathrm{R}^{2}=0.9741$, $\mathrm{r}=0.987, \mathrm{p}<0.001$,

- in 2010-2015: $\mathrm{y}=-4.1477 \mathrm{t}+26.23, \mathrm{R}^{2}=0.9443$, $r=0.972, p=0.001)($ Figure 6).

The mean percentage of sperm with progressive motility in the years 1992-2015 did not change significantly over the analysis period $(r=-0.003, p=0.989)$ (Figure 7).

As shown in Figure 8, the mean viable sperm percentages found in men increased in the years 2000-2015 by 2.085 percentage points annually, on average $(y=2.085 \mathrm{t}$ $\left.+46.630, \mathrm{R}^{2}=0.893, \mathrm{r}=0.944, \mathrm{p}<0.001\right)$. 


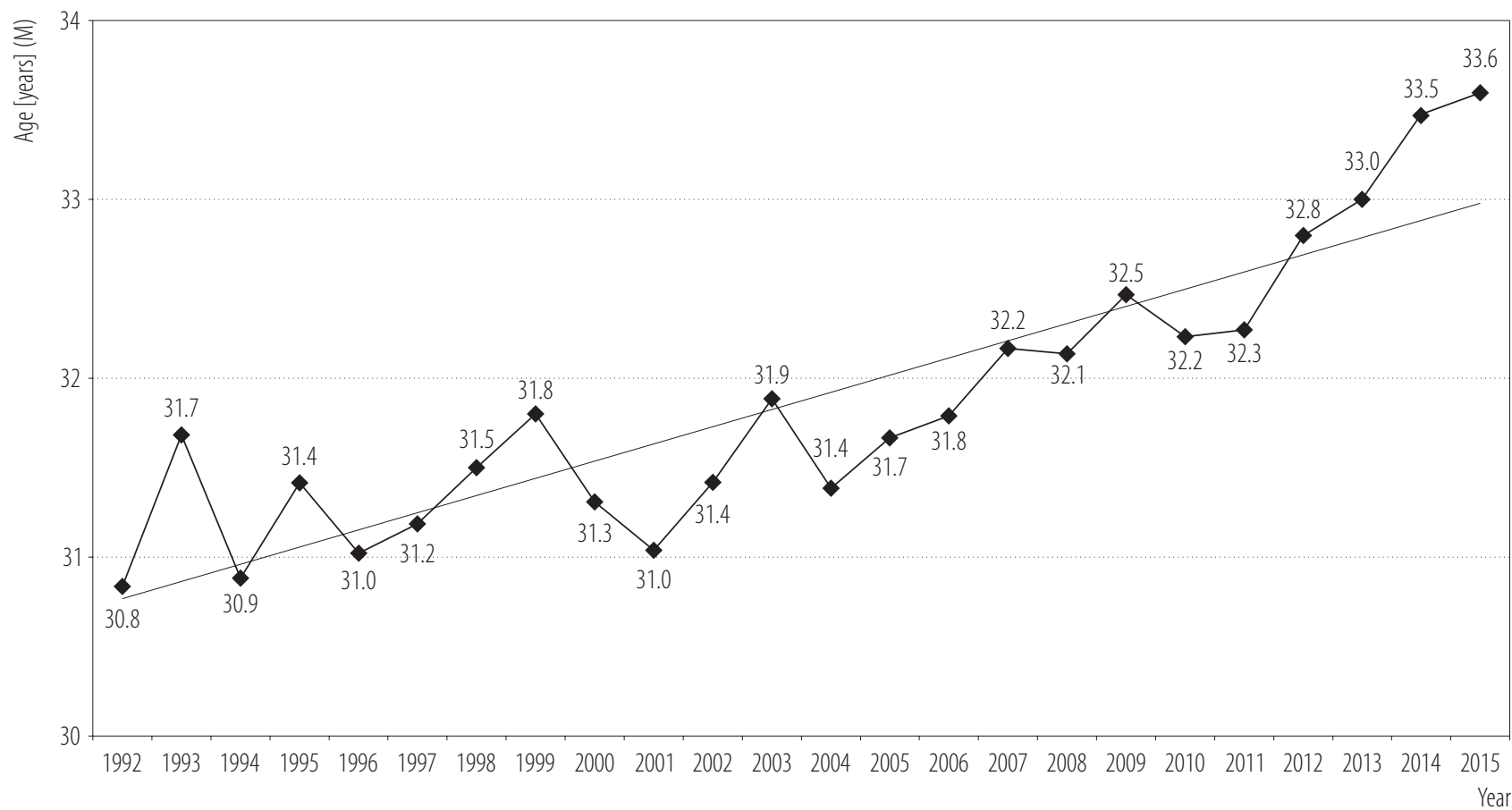
$y=0.096 t+30.673 ; R^{2}=0.779 ; p<0.001$.

Figure 2. Age of the subjects in the Lublin Province, Poland, 1992-2015

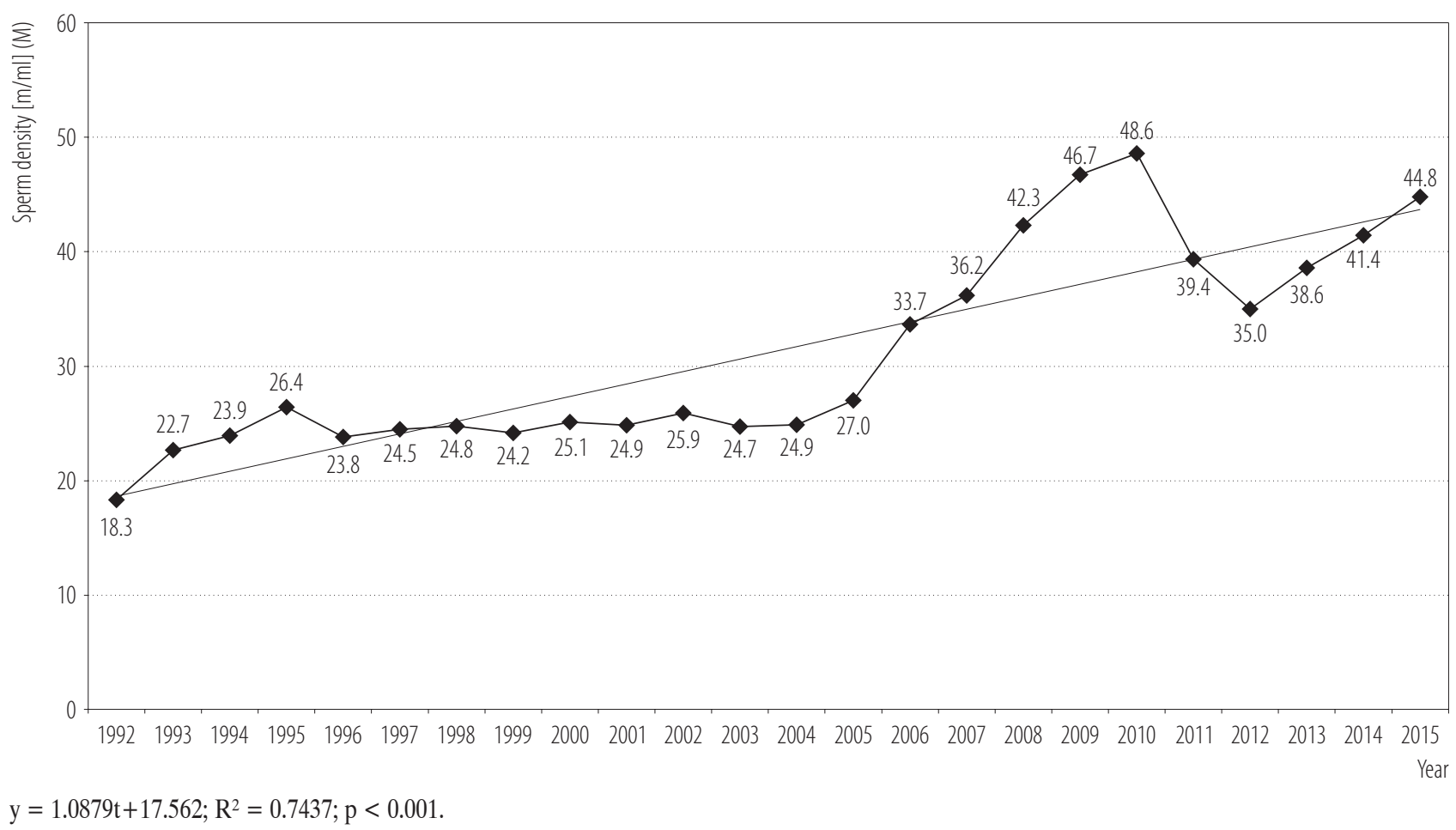

Figure 3. Sperm density in the subjects in the Lublin Province, Poland, 1992-2015 


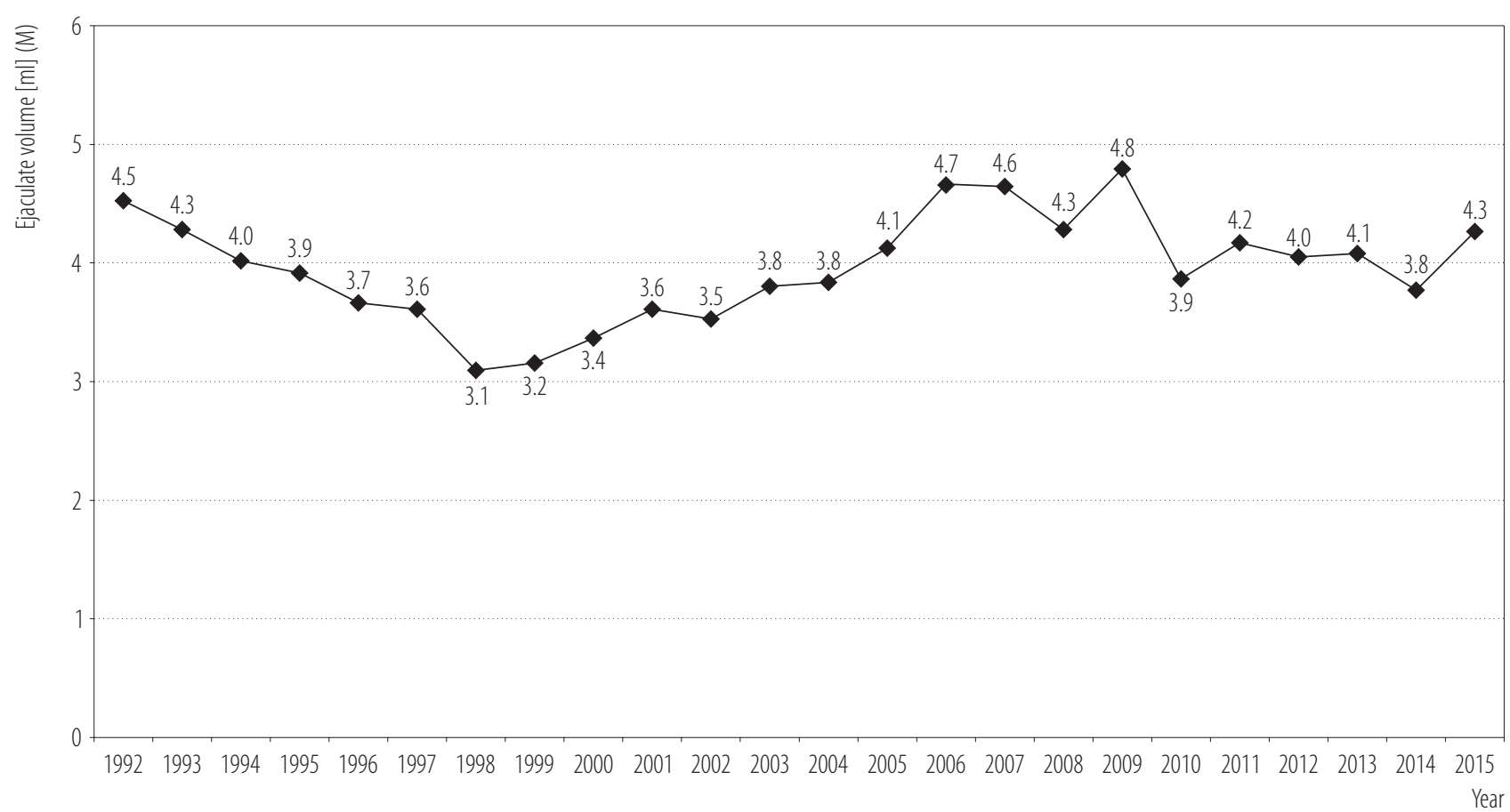
$\mathrm{r}=0.289 ; \mathrm{p}=0.171$.

Figure 4. Ejaculate volume in the subjects in the Lublin Province, Poland, 1992-2015

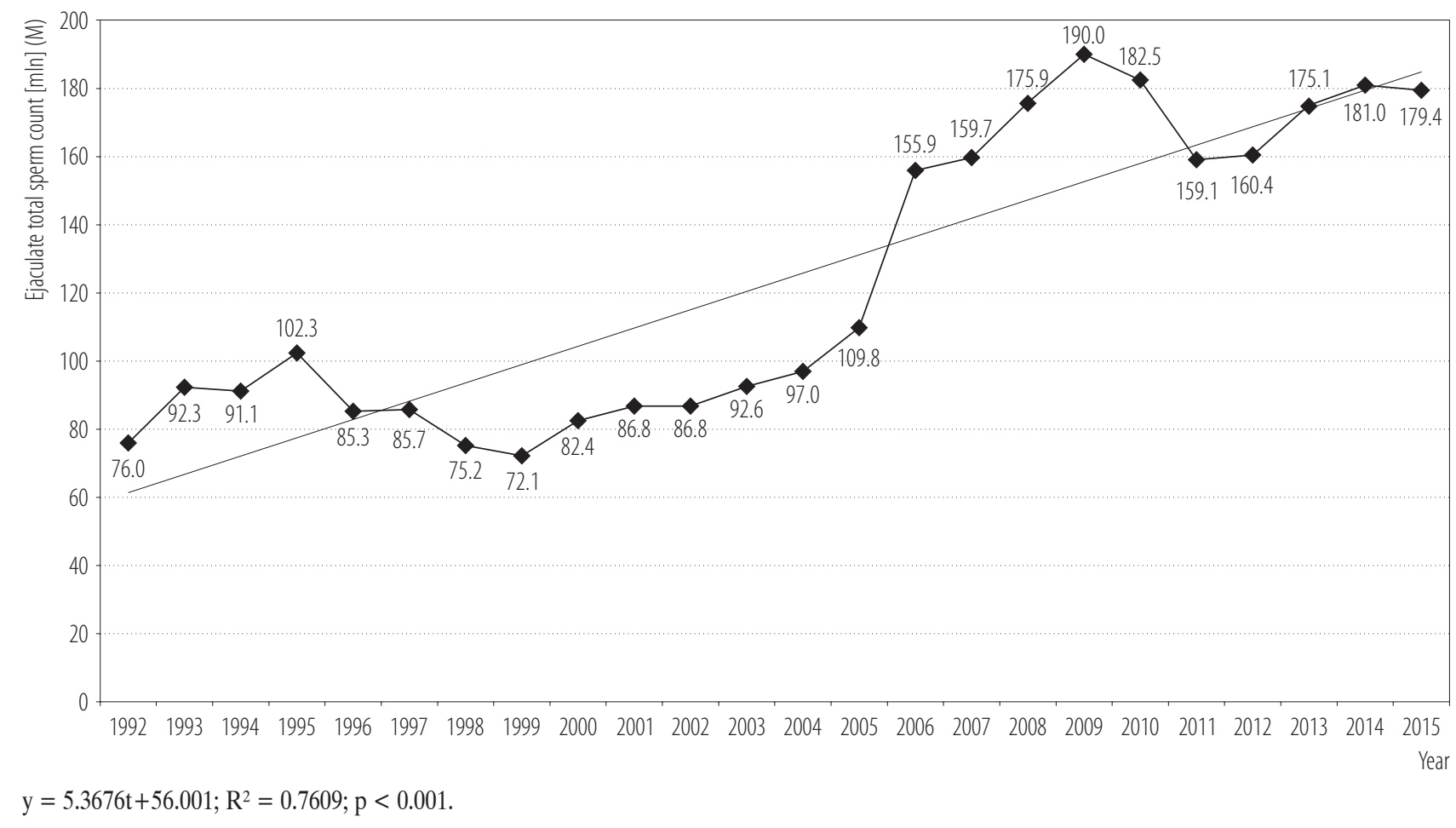

Figure 5. Total sperm count in the ejaculate in the subjects in the Lublin Province, Poland, 1992-2015 


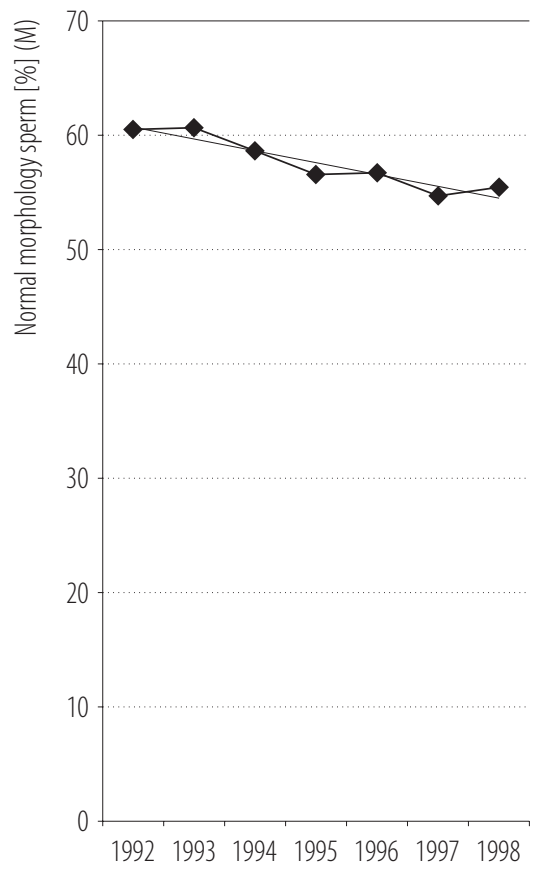

$y=-1.0365 t+61.735 ; R^{2}=0.8915 ;$ $\mathrm{p}=0.001$.

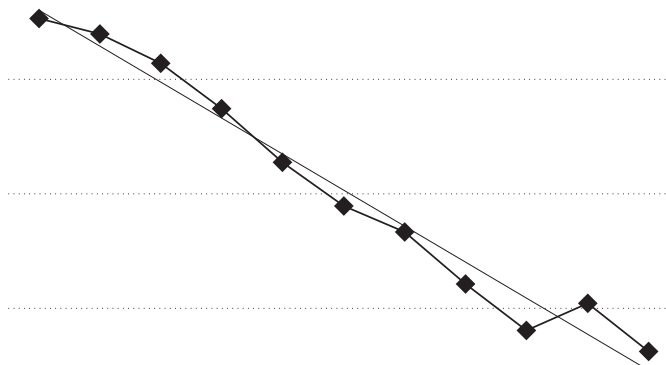

19992000200120022003200420052006200720082009 $y=-3.1521 t+59.233 ; R^{2}=0.9741 ; p<0.001$.

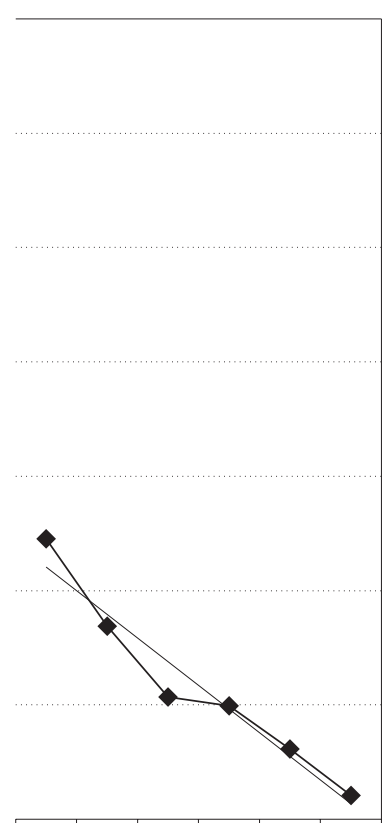

201020112012201320142015

$\mathrm{y}=-4.1477 \mathrm{t}+26.23$

$\mathrm{R}^{2}=0.9443 ; \mathrm{p}=0.001$

Figure 6. Sperm with normal morphology in the subjects in the Lublin Province, Poland, 1992-2015

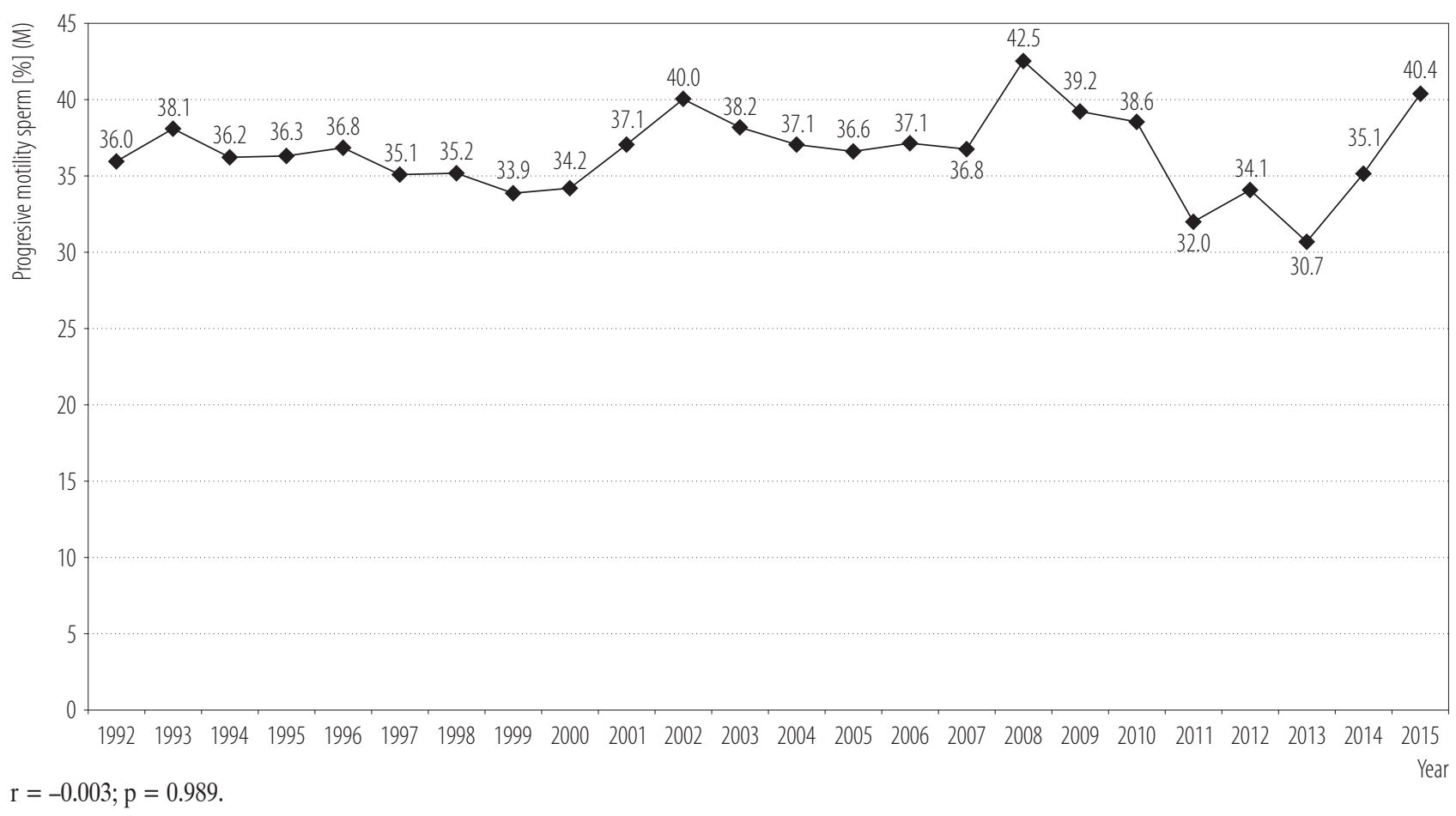

Figure 7. Sperm with progressive motility in the subjects in the Lublin Province, Poland, 1992-2015 


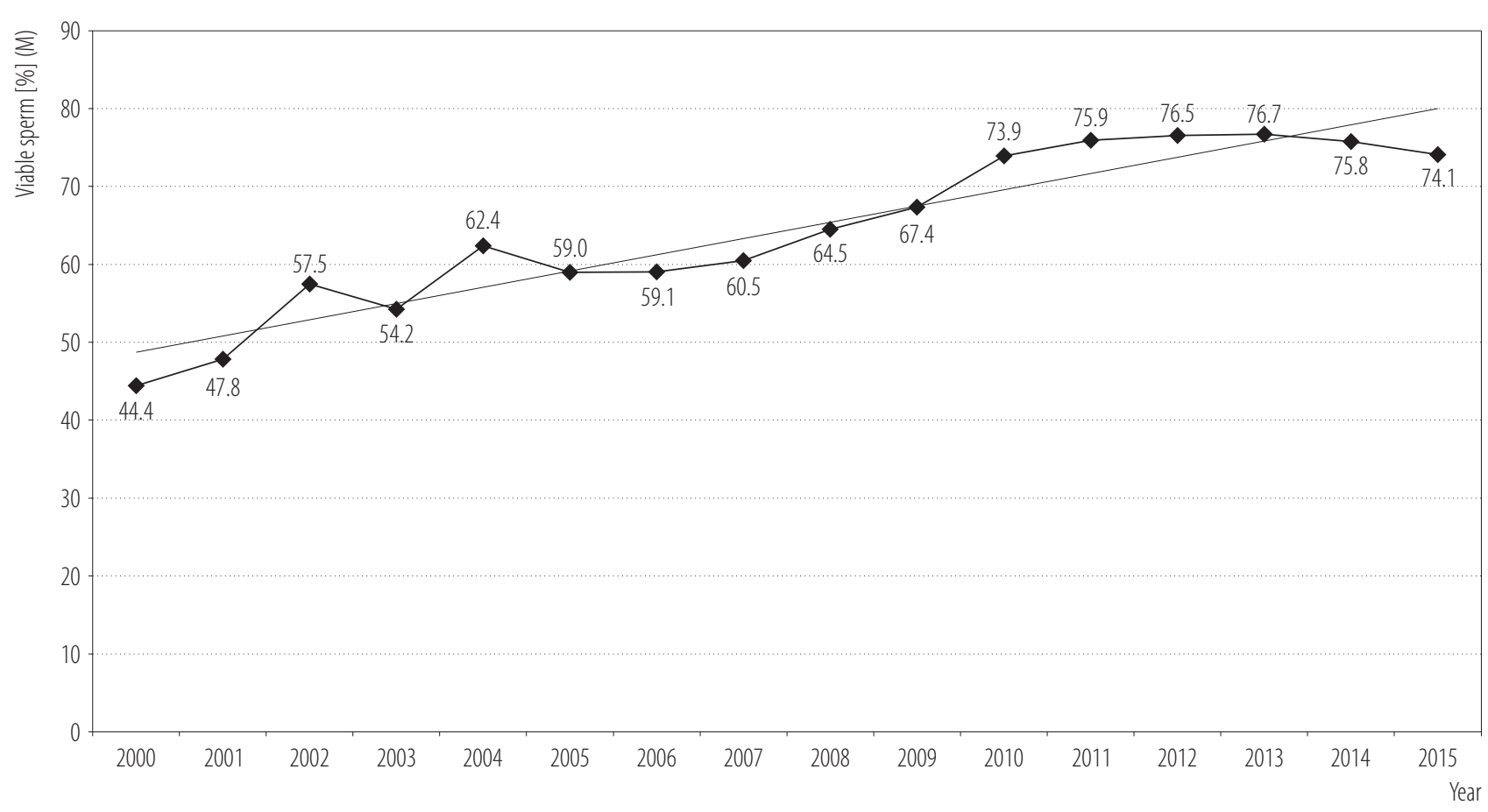

$y=2.085 t+46.630 ; R^{2}=0.893 ; p<0.001$.

Figure 8. Viable sperm of the subjects in the Lublin Province, Poland, 2000-2015

\section{Age and semen parameters}

A significant negative correlation was found between age and the viable sperm percentage - the older the men, the lower was their viable sperm percentage $(r=-0.169$, $p=0.002$ ) (Table 1). Other semen parameters were not significantly correlated with age $(\mathrm{p}>0.05)$.

Table 1. Correlations between age and semen parameters of the subjects who reported for fertility treatment in major reproductive health centers in the Lublin Province, Poland, 1992-2015

\begin{tabular}{lcc}
\hline \multicolumn{1}{c}{ Semen parameter } & $\mathrm{r}$ & $\mathrm{p}$ \\
\hline Ejaculate volume [ml] & -0.037 & 0.459 \\
Total sperm count [m] & -0.015 & 0.759 \\
Sperm density [m/ml] & 0.005 & 0.918 \\
Sperm with progressive motility [\%] & -0.071 & 0.153 \\
Sperm with normal morphology [\%] & 0.024 & 0.637 \\
Viable sperm [\%] & -0.169 & $0.002^{*}$ \\
\hline
\end{tabular}

$* \mathrm{p}<0.05$.

\section{Air pollution and semen parameters}

Data analysis demonstrated a significant negative correlation between the atmospheric ozone levels in the Lublin Province and the percentage of sperm with normal morphology in the men involved in the study in the years 2010-2015 ( $\mathrm{r}=-0.831, \mathrm{p}=0.040)$. No significant correlations were found between other air pollutant levels recorded in the region and other semen parameters in the years 2000-2015 (p > 0.05) (Table 2).

\section{DISCUSSION}

Exposure to air pollution is the main cause of global threats to the environment and to the human population, and contributes to a range of adverse health outcomes, also affecting reproductive health $[7,9,14]$.

The present study demonstrated an increasing trend in sperm density in the men first reporting for fertility treatment in the Lublin Province, and a decreasing trend in the percentage of sperm with normal morphology. The 
Table 2. Correlations between chemical air pollutant levels and mean semen parameters of the subjects in the Lublin Province, Poland, 2000-2015

\begin{tabular}{|c|c|c|c|c|c|c|c|c|}
\hline \multirow{3}{*}{ Semen parameter } & \multicolumn{8}{|c|}{$\begin{array}{c}\text { Chemical air pollutant } \\
{\left[\mu \mathrm{g} / \mathrm{m}^{3}\right]}\end{array}$} \\
\hline & \multicolumn{2}{|c|}{$\mathrm{NO}_{2}$} & \multicolumn{2}{|c|}{$\mathrm{O}_{3}$} & \multicolumn{2}{|c|}{$\mathrm{SO}_{2}$} & \multicolumn{2}{|c|}{$\mathrm{PM}_{10}$} \\
\hline & $\mathrm{r}$ & $\mathrm{p}$ & $\mathrm{r}$ & $\mathrm{p}$ & $\mathrm{r}$ & $\mathrm{p}$ & $\mathrm{r}$ & $\mathrm{p}$ \\
\hline Ejaculate volume [ml] & 0.264 & 0.323 & -0.416 & 0.109 & 0.016 & 0.954 & 0.358 & 0.190 \\
\hline Total sperm count [m] & 0.311 & 0.240 & -0.226 & 0.399 & 0.079 & 0.772 & 0.423 & 0.115 \\
\hline Sperm density $[\mathrm{m} / \mathrm{ml}]$ & 0.283 & 0.289 & -0.220 & 0.413 & 0.216 & 0.422 & 0.476 & 0.071 \\
\hline Sperm with progressive motility [\%] & 0.054 & 0.843 & -0.187 & 0.489 & 0.331 & 0.211 & -0.093 & 0.741 \\
\hline Viable sperm [\%] & 0.369 & 0.160 & -0.238 & 0.374 & -0.199 & 0.460 & 0.425 & 0.113 \\
\hline \multicolumn{9}{|l|}{ Sperm with normal morphology [\%] } \\
\hline $2000-2009$ & -0.303 & 0.395 & 0.445 & 0.084 & 0.013 & 0.972 & -0.513 & 0.158 \\
\hline 2010-2015 & 0.795 & 0.059 & -0.831 & $0.040^{*}$ & 0.423 & 0.104 & 0.219 & 0.677 \\
\hline
\end{tabular}

$* p<0.05$.

findings concerning sperm density are not consistent with those reported by other Polish researchers, including Semczuk et al. [32] in the Lublin Province, and Pająk et al. [33] and Olejek et al. [34] in Silesia (Poland). Olejek et al. [34] performed a retrospective study, including 2116 men who had not been previously treated for infertility. These authors, like those of the present study, found no clinically significant changes in sperm motility [34]. The results reported by Semczuk et al. [32], Pająk et al. [33], and Olejek et al. [34] suggested that the ejaculate volume of Polish men tended to remain stable, which was not confirmed by the present study. One potential cause of the different findings may be the fact that Olejek et al. [34] mainly studied men from a highly industrialized urban area, while the present study included more men from rural areas.

The present analysis of the mean percentages of sperm with normal morphology showed a significantly decreasing trend in the study period, in accordance with both the 1999 and 2010 versions of the WHO guidelines. Similar observations were reported by Semczuk et al. [32], and by Pająk et al. [33], who found consistent decreases in the parameter, while Olejek et al. [34] reported no changes in the subjects' sperm morphology. This clearly suggests the need for ongoing monitoring of changes in sperm morphology in larger groups, and if the decrease is confirmed, also the need to search for a causative factor. A study concerning other regions in the world, performed by Carlsen et al. [20], demonstrated that semen quality has deteriorated considerably in the last 50 years. The study was based on test results from a number of countries, with nearly half of the data concerning the USA. This was continued by Swan et al. [35], who reported a significant decrease in sperm density among the confirmed fertile men in the USA, Europe, and Australia. Mean sperm density was found to decrease by $1.5 \%$ annually in the USA, and by $3 \%$ annually in Europe and Australia, which is a higher rate than that reported by Carlsen et al. (approx. 1\% annually) [20]. Data on the USA and Western Europe are consistent, but reports on Eastern Europe are scarce in the literature on this subject.

Particulate matter (PM) and ground-level ozone $\left(\mathrm{O}_{3}\right)$ are Europe's most problematic pollutants in terms of causing harm to human health, followed by BaP (an indicator for polycyclic aromatic hydrocarbons [PAHs]) and $\mathrm{NO}_{2}$ [4]. The present study demonstrated that exposure 
to $\mathrm{O}_{3}$ in the air contributes to lower percentages of sperm with normal morphology. The adverse impact of air pollution on semen quality was confirmed by Wu et al., who reported a deterioration in sperm morphology with exposure to $\mathrm{PM}_{10}$ and $\mathrm{SO}_{2}$ [36]. In turn, Santi et al. only demonstrated an impact of $\mathrm{PM}_{10}$ on sperm morphology [37]. In another study, Jurewicz et al. demonstrated an association between exposure to $\mathrm{PM}_{2.5}$ and disomy $\mathrm{Y}$, sex chromosome disomy and disomy of chromosome 21, while exposure to $\mathrm{PM}_{10}$ was associated with disomy of chromosome 21 [10]. Radwan et al. [38] stated that $\mathrm{PM}_{2.5}, \mathrm{PM}_{10}, \mathrm{CO}$, and $\mathrm{NO}_{\mathrm{x}}$ had a detrimental impact on sperm morphology, whereas Michniewicz et al. [39] found no correlation between exposure to $\mathrm{NO}_{2}$ or $\mathrm{SO}_{2}$ and a normal sperm percentage, which is consistent with the present findings. Wu et al. [36] demonstrated that exposure to $\mathrm{NO}_{2}$ and $\mathrm{PM}_{10}$ in the air reduced sperm motility, while Santi et al. [37] found no correlation between $\mathrm{PM}_{10}$ exposure and the percentage of progressive sperm, which is in line with the present findings. Lower sperm motility resulting from exposure to air pollutants was also described by De Rosa et al. [40], Guven et al. [41], Boggia et al. [42], and Calogero et al. [43], though the authors did not analyze the impact of specific chemicals present in the air.

The present study did not find evidence for the adverse impact of air pollution on sperm density in the male patients first reporting for fertility treatment. This is consistent with the report by Santi et al. [36] who found no association between $\mathrm{PM}_{10}$ and sperm count per $1 \mathrm{ml}$ of ejaculate, as opposed to $\mathrm{Wu}$ et al. [37] who claimed that exposure to $\mathrm{PM}_{10}$ did reduce sperm density.

Published reports on the impact of air pollution on semen quality are increasingly numerous, but the findings vary greatly. This is certainly due to the differences in research models, on the one hand, and to the presence of other harmful environmental factors in the areas where air pollutants abound, on the other. The main contributors to air pollution include the fuel and energy industry, and the metalworking industry, which are also sources of heavy metal, electromagnetic and heat emissions [44-46]. These factors also have an adverse impact on semen quality. The isolation of specific adverse factors in research models seems to be a difficult and complex task, but the existing scientific reports are alarming and certainly warrant further studies on the subject.

Excessive air pollution may impair the body's antioxidant defense systems. The antioxidant defense system of semen includes enzymatic and non-enzymatic factors that interact to provide optimum protection against reactive oxygen species (ROS) [18]. A deficiency of any of these factors may reduce the overall antioxidant capacity. As ROS are highly reactive, they quickly react with proteins, lipids and nucleic acids, also initiating chain reactions, and induce the formation of other free radical products. Oxidative stress results in damage to cellular macromolecules, leading to dysfunction and, ultimately, to cell death $[47,48]$.

Ozone is a strong oxidant, and ozone reactions produce free radicals. The exact mechanism whereby ozone affects spermatogenesis has not been fully understood yet. One may expect it to be similar to that described by Khairallah et al. [49] with regard to proteins in the lungs.

The intrinsic reactivity of ozone with proteins can be understood by first analyzing its reactions with deprotonated cysteine $[\mathrm{Cys}-\mathrm{H}](-)$ in the gas phase. The reaction, occurring near the collision limit, yields a variety of products, including cysteine sulfenate, sulfinate and sulfonate anions formed by sequential oxygen atom abstractions, as well as sulfenate radical anions produced by hydroperoxy radical ejection. Electron transfer seems to be key to this reaction, as the free-radical pathway only occurs in the presence of both thiol and carboxylate moieties. The reaction also occurs in small cysteine containing peptides, which suggests a potential association with ozone-protein reactions [49]. Whereas female fertility decreases over time, and ultimately ceases, reports regarding an analogous process in men are inconclusive. In the present study, no statistically significant associations were found between age and sperm density or 
total sperm count. Only the percentage of viable sperm decreased with age. Johnson et al. performed a meta-analysis summarizing the published results of 90 studies (which included 93839 cases) [50]. The authors reported that sperm density did not change with age, though ejaculate volume, the percentage of normal sperm, and the percentage of sperm with progressive motility indeed decreased, which is in contrast to the present findings. This difference may be due to the fact that the study by Johnson et al. [50] involved a population of healthy men of various ages, rather than predominantly middle-aged men with fertility problems.

The potential differences in either exposure to air pollutants or living conditions, found between various countries, imply that there are still no clear answers regarding the impact of these factors on male fertility. However, this can be an indication of directions for further studies aimed at monitoring the reproductive health of the population. In the future, such studies may offer an opportunity to implement timely preventive actions with regard to exposure to harmful factors, and to increase environmental awareness in the society.

\section{CONCLUSIONS}

Exposure to ozone in the air contributes to decreased percentages of sperm with normal morphology. Over the years, there has been an increasing trend in sperm density in the men first reporting for fertility treatment, and a decreasing trend in the percentages of sperm with normal morphology. The age of men adversely affects the percentage of viable sperm in their semen.

\section{REFERENCES}

1. Colao A, Muscogiuri G, Piscitelli P. Environment and health: not only cancer. Int J Environ Res Public Health. 2016;13(7):E724, https://doi.org/10.3390/ijerph13070724.

2. Wdowiak A, Wdowiak E, Bakalczuk G, Bojar I. [The influence of air pollution on human reproduction]. Postepy Hig Med Dosw. 2018;72:35-42, https://doi.org/10.5604/01.3001. 0010.8700. Polish.
3. 97/101/EC: Council Decision of 27 January 1997 establishing a reciprocal exchange of information and data from networks and individual stations measuring ambient air pollution within the Member States. OJ 1997 L35. p. 14-22.

4. European Environment Agency. Air quality in Europe 2017 report no. 13/2017. Luxembourg: Publications Office of the European Union; 2017.

5. Program Państwowego Monitoringu Środowiska na lata 2016-2020. Warszawa: Główny Inspektor Ochrony Środowiska; 2015. Polish.

6. World Health Organization. Air quality guidelines. Global update 2005. Copenhagen: The Organization; 2006.

7. Lelieveld J, Evans JS, Fnais M, Giannadaki D, Pozzer A. The contribution of outdoor air pollution sources to premature mortality on a global scale. Nature. 2015;525(7569):367-71, https://doi.org/10.1038/nature15371.

8. Nieuwenhuijsen MJ, Basagaña X, Dadvand P, Martinez D, Cirach M, Beelen R, et al. Air pollution and human fertility rates. Environ Int. 2014;70:9-14, https://doi.org/10.1016/ j.envint.2014.05.005.

9. Chen EK, Zmirou-Navier D, Padilla C, Deguen S. Effects of air pollution on the risk of congenital anomalies: a systematic review and meta-analysis. Int J Environ Res Public Health. 2014;11(8):7642-68, https://doi.org/10.3390/ ijerph110807642.

10. Jurewicz J, Radwan M, Sobala W, Polańska K, Radwan P, Jakubowski L, et al. The relationship between exposure to air pollution and sperm disomy. Environ Mol Mutagen. 2015;56(1):50-9, https://doi.org/10.1002/em.21883.

11. Jurewicz J, Radwan M, Wielgomas B, Sobala W, Piskunowicz M, Radwan P, et al. The effect of environmental exposure to pyrethroids and DNA damage in human sperm. Syst Biol Reprod Med. 2015;61(1):37-43, https://doi.org/10.3109/1939 6368.2014.981886.

12. Frutos V, González-Comadrán M, Solà I, Jacquemin B, Carreras R, Checa Vizcaíno MA. Impact of air pollution on fertility: a systematic review. Gynecol Endocrinol. 2015;31(1): 7-13, https://doi.org/10.3109/09513590.2014.958992. 
13. Jeng HA, Pan CH, Chao MR, Chiu CC, Zhou G, Chou CK, et al. Sperm quality and DNA integrity of coke oven workers exposed to polycyclic aromatic hydrocarbons. Int J Occup Med Environ Health. 2016;29(6):915-26, https://doi. org/10.13075/ijomeh.1896.00598.

14. Jurewicz J, Radwan M, Wielgomas B, Kałużny P, Klimowska A, Radwan P, et al. Environmental levels of triclosan and male fertility. Environ Sci Pollut Res Int. 2018;25(6): 5484-90, https://doi.org/10.1007/s11356-017-0866-5.

15. Vecoli C, Montano L, Andreassi MG. Environmental pollutants: genetic damage and epigenetic changes in male germ cells. Environ Sci Pollut Res Int. 2016;23(23):23339-48, https://doi.org/10.1007/s11356-016-7728-4.

16. Radwan M, Dziewirska E, Radwan P, Jakubowski L, Hanke W, Jurewicz J. Air pollution and human sperm sex ratio. Am J Mens Health. 2018;12(4):907-12, https://doi. org $/ 10.1177 / 1557988317752608$.

17. Showell MG, Mackenzie-Proctor R, Brown J, Yazdani A, Stankiewicz MT, Hart RJ. Antioxidants for male subfertility. Cochrane Database Syst Rev. 2014;(12):CD007411, https:// doi.org/10.1002/14651858.CD007411.pub3.

18. Wdowiak A, Bakalczuk S, Bakalczuk G. Decreased activity of superoxide dismutase in the seminal plasma of infertile men correlates with increased sperm deoxyribonucleic acid fragmentation during the first hours after sperm donation. Andrology. 2015;3(4):748-55, https://doi.org/10.1111/andr.12061.

19. Aanesen A, Westerbotn M. Prospective study of a Swedish infertile cohort 2005-08: population characteristics, treatments and pregnancy rates. Fam Pract. 2014;31(3):290-7, https://doi.org/10.1093/fampra/cmu003.

20. Carlsen E, Giwercman A, Keiding N, Skakkebaek NE. Evidence for decreasing quality of semen during past 50 years. BMJ. 1992;305(6854):609-13, https://doi.org/10. 1136/bmj.305.6854.609.

21. Wdowiak A, Wdowiak A, Moroz E, Bojar I. Comparison of selected sperm parameters between 6,278 males in Poland and Ukraine. Ann Agric Environ Med. 2016;23(1):174-81, https://doi.org/10.5604/12321966.1196876.
22. Daly I, Bewley S. Reproductive ageing and conflicting clocks: King Midas' touch. Reprod Biomed Online. 2013;27(6): 722-32, https://doi.org/10.1016/j.rbmo.2013.09.012.

23. Meldrum DR, Casper RF, Diez-Juan A, Simon C, Domar AD, Frydman R. Aging and the environment affect gamete and embryo potential: can we intervene? Fertil Steril. 2016;105(3): 548-59, https://doi.org/10.1016/j.fertnstert.2016.01.013.

24. Baldacci S, Gorini F, Minichilli F, Pierini A, Santoro M, Bianchi F. [Review of epidemiological studies on individual and environmental risk factors in the aetiology of congenital heart defects]. Epidemiol Prev. 2016;40(3-4):185-96, https:// doi.org/10.19191/EP16.3-4.P185.085. Italian.

25. World Health Organization. Review of evidence on health aspects of air pollution - REVIHAAP project. The Organization; 2013.

26. Wdowiak A, Mazurek PA, Wdowiak A, Bojar I. Effect of electromagnetic waves on human reproduction. Ann Agric Environ Med. 2017;31(1):13-8, https://doi.org/10.5604/ 12321966.1228394.

27. Chen Q, Hong X, Song Y, Sun Q, Wang J. Effects of diesel exhaust particles on the quality of mouse sperm. Chin J Androl. 2009;23(3):22-5.

28. Ema M, Naya M, Horimoto M, Kato H. Developmental toxicity of diesel exhaust: a review of studies in experimental animals. Reprod Toxicol. 2013;42:1-17, https://doi. org/10.1016/j.reprotox.2013.06.074.

29. World Health Organization. WHO Laboratory Manual for the Examination of Human Semen and Sperm-cervical Mucus Interaction. 3th ed. The Organization; 1992.

30. World Health Organization. WHO Laboratory Manual for the Examination of Human Semen and Sperm-cervical Mucus Interaction. 4th ed. Cambridge University Press; 1999.

31. World Health Organization. WHO Laboratory Manual for the Examination and Processing of Human Semen. 5th ed. Geneva: The Organization; 2010.

32. Semczuk M, Kraczkowski J, Kalasiewicz J, Pakuła H, Franczak J. [The morphology index of semen of men from 
Lublin Region between 1990 and 1994]. Ginekol Pol. 1995;66(2):86-91. Polish.

33. Pająk J, Heimrath J, Barwiński J. [Changes in the morphological image of the semen of men from childless married couples residents of the Lower Silesian region in 1997-1993]. Ginekol Pol 1999;70(1):20P. Polish.

34. Olejek A, Tomanek G. [Analysis some of semen parameters according to patients residence in the Infetrtility Outpatient Clinic in Bytom]. Ginekol Prakt. 2005;1(7):8-13. Polish

35. Swan SH, Elkin EP, Fenster L. The question of declining sperm density revisited: an analysis of 101 studies published 1934-1996. Environ Health Perspect. 2000;108(10):961-6, https://doi.org/10.1289/ehp.00108961.

36. Wu L, Jin L, Shi T, Zhang B, Zhou Y, Zhou T, et al. Association between ambient particulate matter exposure and semen quality in Wuhan, China. Environ Int. 2017;98:219-28, https://doi.org/10.1016/j.envint.2016.11.013.

37. Santi D, Vezzani S, Granata AR, Roli L, De Santis MC, Ongaro C, et al. Sperm quality and environment: A retrospective, cohort study in a Northern province of Italy. Environ Res. 2016;150:144-53, https://doi.org/10.1016/j.envres.2016.05.053.

38. Radwan M, Jurewicz J, Polańska K, Sobala W, Radwan P, Bochenek M, et al. Exposure to ambient air pollution-does it affect semen quality and the level of reproductive hormones? Ann Hum Biol. 2016;43(1):50-6, https://doi.org/10. 3109/03014460.2015.1013986.

39. Michniewicz J, Pajak J, Hirnle L, Barwiński I, Heimrath J. Semen analysis results and air pollution in the group of men from infertile couples in the Lower Silesia in 1977-2000. Ginekol Pol. 2001;12:977-82.

40. De Rosa M, Zarrilli S, Paesano L, Carbone U, Boggia B, Petretta M, et al. Traffic pollutants affect fertility in men. Hum Reprod. 2003;18(5):1055-61, https://doi.org/10.1093/ humrep/deg226.

41. Guven A, Kayikci A, Cam K, Arbak P, Balbay O, Cam M. Alterations in semen parameters of toll collectors working at motorways: does diesel exposure induce detrimental effects on semen? Andrologia. 2008;40(6):346-51, https://doi. org/10.1111/j.1439-0272.2008.00867.x.

42. Boggia B, Carbone U, Farinaro E, Zarrilli S, Lombardi G, Colao A, et al. Effects of working posture and exposure to traffic pollutants on sperm quality. J Endocrinol Invest. 2009;32(5):430-4, https://doi.org/10.1007/BF03346481.

43. Calogero AE, La Vignera S, Condorelli RA, Perdichizzi A, Valenti D, Asero P, et al. Environmental car exhaust pollution damages human sperm chromatin and DNA. J Endocrinol Invest. 2011;34(6):e139-43, https://doi.org/10.1007/BF03346722.

44. Mazurek P, Boś B, Wdowiak A, Naumchuk O. Dosimetry of the electromagnetic fields of the GSM/UMTS/WLAN band. Eur J Med Technol. 2016;1(10):15-24.

45. Samek L. Overall human mortality and morbidity due to exposure to air pollution. Int J Occup Med Environ Health. 2016;29(3):417-26, https://doi.org/10.13075/ijomeh. 1896.00560 .

46. Mazurek A, Wdowiak A, Anusiewicz A. Electromagnetic interactions of metal detectors. Eur J Med Technol. 2017; 1(14):33-40.

47. Kreuz S, Fischle W. Oxidative stress signaling to chromatin in health and disease. Epigenomics. 2016;8(6):843-62, https://doi.org/10.2217/epi-2016-0002.

48. Poljsak B. Strategies for reducing or preventing the generation of oxidative stress. Oxid Med Cell Longev. 2011;2011:194586, https://doi.org/10.1155/2011/194586.

49. Khairallah GN, Maccarone AT, Pham HT, Benton TM, Ly T, da Silva G, et al. Radical formation in the gas-phase ozonolysis of deprotonated cysteine. Angew Chem Int Ed Engl. 2015;26;54(44):12947-51, https://doi.org/10.1002/anie. 201506019.

50. Johnson SL, Dunleavy J, Gemmell NJ, Nakagawa S. Consistent age-dependent declines in human semen quality: a systematic review and meta-analysis. Ageing Res Rev. 2015;19:22-33, https://doi.org/10.1016/j.arr.2014.10.007.

This work is available in Open Access model and licensed under a Creative Commons Attribution-NonCommercial 3.0 Poland License - http://creativecommons.org/ licenses/by-nc/3.0/pl/deed.en. 